på hånden, fordi der var fællestræk ved nazismen og socialismen, som var af endnu mere afgørende betydning end økonomien, fx myrderier $\mathrm{i}$ en ideologis tjeneste.

Men sådan er det hele tiden med Zizek, der sprænges vedvarende nogle klassiske forståelsesrammer. Han ville fx være stolt af at kunne få lov til at være lige så farlig for kapitalismen, som kapitalismen er for mennesket. At arbejde med Zizek er som at få sine politiske og eksistentielle tanker psykoanalyseret. Man bliver formodentlig ikke rask af denne psykoanalyse, men om ikke andet kan man få modet til i dybeste forstand at tænke over tingene.

Ole Morsing

\section{Liberalismen set igennem og imod Schmitt}

Mikekel Thorup (red.): Den ondeste mand $i$ live? Lasninger af og mod Carl Schmitt, Museum Tusculanums Forlag, 2007, 210 sider, $198 \mathrm{kr}$.

Den fortsat voksende interesse $\mathrm{i}$ international politisk teori for den kontroversielle tyske retstænker, Carl Schmitt, har også sat sine tydelige spor i Danmark de senere år. Der er nu udkommet en Schmitt-antologi-den første af sin art i Danmark - dedikeret til en kritisk diskussion af forfatterskabets grundbegreber og analytiske tilgange. Der er i flere henseender tale om en væsentlig udgivelse.
I flere henseender, fordi antologien ikke kun tematiserer Schmitts forfatterskab, men tillige vores politiske samtid og nære fortid. Antologien giver vigtige indblik $\mathrm{i}$ undermineringer af retsprincipper og manipulationer af demokratiet; i krige, der ikke kaldes krige, og undtagelsestilstande, der fornægtes; i synlige og usynlige kombattanter og i skjult suverænitetsudøvelse. Disse fænomener lokaliseres $i$ kernen af det liberale Vesten og analyseres i spil med Schmittske kernebegreber som 'undtagelsestilstand', 'nødret', 'suverænitet' samt hans krigs- og fjende-differentieringer. Derudover tilbyder antologien skarpe og stærkt tiltrængte afklaringer af implikationerne af Schmitts begreber. Anstødsstenen for mange af forfatterne er den ureflekterede og ukritiske overtagelse af Schmitts begreber, som findes i store dele af receptionen.

Det er antologiens sigte at bidrage til en affortryllelse af Schmitt. Mikkel Thorups indledning spiller elegant og flertydigt på Schmitts liberalismekritiske hovedfigur: Liberalismens forsøg på at undertvinge alvorlige politiske konflikter resulterer i det politiskes genkomst på en grusommere måde. 'Forbuddet, der betinger genkomsten', i Thorups formulering. Årtiers skandalisering af Schmitt grundet hans nazi-engagement har resulteret $i$ hans genkomst $i$ en aura af farlighed, med både tilbedelsens og fordømmelsens mytologiseringer til følge. 
Bidragene falder - deres diversitet til trods - for denne anmelders blik i tre forskellige spor. I det første spor, der udgøres af antologiens to første og to sidste artikler og således markerer dens 'ramme', analyseres samtidige eller historiske fænomener igennem en Schmittsk optik.

Gert Sørensen fremstiller interessant og oplysende, hvordan Schmitt i 1930'erne formidlede nazismens idé til grupper af italienske retskyndige. Sørensen belyser nazistyrets (a)juridiske grundtræk både igennem og op imod Schmitts beskrivelser heraf, - og trækker tråde til det italienske demokratis betændte historie og samtid. Artiklens stærke hovedpointe er at pege på det nationale demokratis skrøbelighed i kraft af dets afhængighed af et statsapparat. Sørensen slår ned på en afgørende retsfilosofisk problemstilling i Schmitts nazismeforsvar: Schmitt antager en 'legal bro' der fører fra Weimarforfatningen til naziregimets suspension af samme. Sørensen afviser en sådan antagelse på det skarpeste: tværtimod var overgangen mellem de to kvalitativt forskellige regimer kendetegnet ved rå vold og a-legalitet.

Frederik Roséns artikel giver til gengæld et eksempel på, at substantielle retsskred kan realiseres igennem legaliteten. Rosén argumenterer overbevisende for, at Udlændingelovens $\$ 45$ institutionaliserer en permanent nødretsforanstaltning i dansk ret, hvilket indebærer ophævelsen af en klar kompetencefordeling mellem administrative, politiske og juridiske beslutninger i forbindelse med Flygtningenævnets afgørelser. Artiklen retter blikket mod en foruroligende retsudvikling - og indeholder tillige vigtige teoretiske overvejelser over forholdet mellem undtagelse og normalitet, retsskabelse og retskonservering.

Mikkel Thorup sætter fokus på undtagelsestilstandens forekomst i samtiden som et globalt fænomen. Artiklen er fremragende både som Schmitt-læsning og samtidsanalyse betragtet: Den går på nuanceret vis i kødet på senforfatterskabets folkeret, og den udfolder herigennem en kompleks samtidig problemstilling, ved en tilgang, der må betegnes som både med-, mod- og videre-læsning. Artiklens hovedpointe er generaliseringen af den globale undtagelsestilstand, kaldet 'grænselandet'. På grundlag af sammenbruddet af klare geografiske skel imellem 'indezoner' (af vestlig fred, sikkerhed og overflod) og 'udezoner' (af lovløshed og fjendskab) ses i den vestlige verden 'febrilske forsøg på udpegninger af fjenden' samt bestræbelser på at forskyde grænselandet væk fra den vestlige verden. Thorup analyserer Krigen mod terror og den vestlige verdens humanitære interventioner som udtryk herfor.

Pointen i Ola Tunanders mindst lige så fremragende artikel kan siges at være den modsatte: Tunander påviser bevidste bestræbelser på at skyde 'grænselandet' ind i kernen af den vestlige verden, ikke forskyde det 
væk. Han argumenterer skarpt og på grundlag af righoldig empirisk dokumentation for eksistensen af et hemmeligt sikkerhedshierarki, der under den kolde krig opererede parallelt med NATO's formelle organisation og styrede et større antal paramilitære enheder, der udførte terrorhandlinger, likvideringer og militærkup i NATO-landene. Tunander ser dette sikkerhedshierarki gennem Schmitts suverænitetsbegreb og Morgenthaus idé om dobbelstaten, nemlig som udtryk for en parallelstruktur til demokratiet, hvilken ikke blot begrænser men også finjusterer de demokratiske processer - eks. ved politisk manipulation af folkestemninger gennem terrorhandlinger.

I antologiens andet spor går tre forfattere i begrebslig nærkamp med Schmitts ven-fjende-kriterium for det politiske.

Anne-Marie Eggert Olsen angriber den ubekymrede Schmitt-reception, der breder sig i både intellektuelle venstre- og højre-kredse, og som i Schmitts 'begreb for det politiske' ser en ny mulig vej for den politiske filosofi. Artiklen analyserer knivskarpt Schmitts begrundelse for og bestemmelse af 'det politiskes begreb' i værket af samme navn. Eller rettere: fraværet af begge, som analysen viser. Når Schmitt hævder skellet mellem ven og fjende som definerende for det politiske stipulerer han udelukkende, fastlægger et kriterium for inklusion og eksklusion; at tale om et 'begreb' er en filosofisk tilsnigelse af rang.

Heri ligger en vigtig filosofisk præcisering. Ven-fjende-skellet må forstås som et kriterium, hvis formål det er at udpege forskellige intensiteter af stridsforhold i et empirisk rum, der er politisk diffust. Det er heri et udtryk for Schmitts grundlæggende stridsblik på det historiske menneskeliv. Dette blik begrundes ikke $i$ andet end i postulatet om ven-fjende-skellet som et uophørligt menneskeligt vilkår.

Emily Hartz argumenterer overbevisende for, at ven-fjende-kriteriet må tilskrives status som ontologisk grundantagelse i forfatterskabet - og rejser hermed spørgsmålet om forholdet mellem ontologi(sering) og historisk, empirisk analyse i forfatterskabet. Ifølge Hartz skelner Schmitt ikke klart imellem de ontologiske og de empirisk/historiske lag i sine værker. Hun analyserer Nomos der Erde og Theorie des Partisanen og konkluderer, at argumentationen i værkerne, deres empiriske mangfoldighed til trods, er båret af den ontologiske grundantagelse.

Uanset om Hartz har ret i, at ontologien driver argumentationen i værkerne, så er hendes hovedpointe afgørende: Hvis Schmitts liberalismekritik skal kunne anvendes konstruktivt i samtiden, så forudsætter det en frigørelse af forfatterskabets historisk/empiriske argumenter fra de ontologiske forudsætninger.

Antologiens tredje analyse af kriteriet, Lars Bo Larsens, peger lige ind i dets kerneproblemstilling: er det et 
refleksionsløst redskab, der kun formår teoretisk at mime den faktisk forekommende vold? Larsen karakteriserer kriteriet på følgende krystalklare måde: Som svar på den moderne udfordring forskyder Schmitt den politiske substans til relationen. Men denne redning sætter en perverteret eksistentialisme i stedet: volden bliver et kriterium for liv og politik. Larsen belyser skarpsindigt denne pointe hen over Schmitts forhold til Stirner, men slutter hos Hegel. Hegel havde det svar, som Schmitt ikke fandt, ifølge Larsen: at opfatte sandheden ikke som substans, men som subjekt, som formidlende eksistens.

Man kunne spørge, om ikke venfjende-kriteriets teoretiske potentiale netop ligger deri, at udpegningen af vennen og fjenden og forholdets karakter aldrig er fikseret udefra, men altid kun eksisterer subjektivt formidlet, $\mathrm{i}$ kraft af de involveredes gensidigt afhængige erkendelse? I sit fængselsskrift Ex Captivate Salus lægger Schmitt op til et hegeliansk perspektiv på sit kriterium, til en anerkendelses dialektik. Om dette potentiale indløses i forfatterskabet er dog et helt andet spørgsmål.

I antologiens tredje spor placeres Schmitt i det politiske og demokratiteoretiske samtidsbillede. Fælles afsæt for de tre forfattere er opgøret med venstre-intellektuelles anvendelse af Schmitts konfliktperspektiv i demokrati- og pluralisme-øjemed.

Torben Bech Dyrberg fremhæver Schmitts opfordringer til kollektivi- stisk identitetspolitik, baseret på klare fjendebilleder og folkets identifikation med en elitær suveræn vilje. Artiklen har direkte adresse til Chantal Mouffe: hendes anvendelse af Schmitts politikdefinition er baseret på den fejlagtige forudsætning, at den er en 'tom formel for identitets- og meningsdannelse', der kan gives et vilkårligt indhold, og hendes forsøg på at indsætte ven-fjende-distinktionen i en liberal orden ved at opbløde modsætningen ('modstanderen' frem for 'fjenden') er vag og ukonkret.

Men er ven-fjende-distinktionen ikke en sådan substansløs formel, der kan gives et hvilket som helst indhold, også et andet end 'folket'? Således i hvert fald Eggert Olsen og Larsen. Dyrberg har dog en stærk pointe $i$ at pege på, at det ikke er indlysende, hvordan pluralistiske idealer om anerkendelsesforhold mellem fjender, der knytter sig til en folkeretslig sammenhæng, kan overføres til en forfatningsretlig. Denne problemstilling bliver afgjort ikke mindre af, at man erstatter de hårde begreber med nogle blødere.

Søren Hviid Pedersen belyser på rammende vis Schmitt som en konservativ tænker. Schmitts position reflekteres dels gennem konservatismens generelle forudsætninger, nemlig fundamental mistillid til menneskelig fornuft og betoningen af autoritet, social orden og institutioner; dels gennem et radikalt eller revolutionært perspektiv, der tilsiger, at de overleverede institutioner er histo- 
risk udhulede. Endelig karakteriseres Schmitt som en udpræget europæisk (i modsætning til amerikansk) konservativ, ved sin betoning af staten og af legitimitetens immanens.

Endelig demonstrerer Gorm Harste, hvorledes Schmitt repræsenterer et angreb på magtdelingslæren gennem sin politiske fordring om en suveræn, der i undtagelsestilstanden kan suspendere skellene imellem moral, politik, forvaltning og ret, og gennem et teoriapparat, der forbliver fanget i enhedsforestillinger. Artiklen diskuterer Schmitts placering indenfor tysk politisk teori, idet Schmitt konfronteres med Kant, Habermas og Luhmann.

For en helhedsbetragtning reflekterer antologien væsentlige problemstillinger, både vedrørende vores politiske nationale og globale samtid, og vedrørende læsningen af Schmitt. Det er efter min opfattelse de empirisk orienterede artikler, der for alvor begrunder relevansen af en Schmittantologi i dag. De viser, at vi har brug for teoretiske tilgange, der kan åbne blikket og analysen for forekomsten af undtagelsestilstande og nødlove, undermineringer af demokrati og retsstat, modsigelsesramte fjendeudpegninger og fjendskabsintensiveringer - fordi alt dette faktisk foregår, mere eller mindre synligt, og ikke blot udenfor, men i kernen af det liberale vesten. For at citere Tunanders afslutning: "Thus, the problem with liberalism in political science and legal theory is not its ambition to defend the public sphere, political freedom and human rights, but rather its claim that these freedoms and rights define the Western political system."

De empirisk orienterede artikler peger på, at Schmitts vægtige bidrag i dag består $i$ at kunne åbne det analytiske blik for, hvad liberalismen fornægter og lyver om. De begrebsanalytiske artikler peger på to afgørende betingelser for muligheden heraf: For det første, at ven-fjende-distinktionen ikke overtages af receptionen som et rigidt redskab; her er Eggert Olsens og Larsens kritikker værdifulde. Efter min opfattelse viser Thorup i sin artikel - ved bl.a. at tematisere 'febrilske fjende-udpegninger' og 'udeinde-distinktionens sammenbrud' - at en differentieret og dialektisk anvendelse af kriteriet er mulig. For det andet, som Hartz fremhæver, at Schmitt-receptionen formår at uddrage argumentstrukturer af forfatterskabets historiske overvejelser, der ikke er determineret af dets ontologiske forudsætninger.

Hvad det andet punkt angår, så savner jeg i antologien de historiskbegrebslige aspekter af Schmitts liberalismekritik stærkere repræsenteret, navnlig hvad forfatningsretten angår. I hovedparten af bidragene læses liberalismekritikken ontologisk, med en tendens til at fortolke den som udtryk for en art dyrkelse af fjendskabet for dets egen skyld og en deraf følgende afvisning af liberalismen som udtryk for konturløs debat og gennemført afpolitisering. Sådan kan 
man læse den; men eftersom verden i dag befinder sig lige så langt fra en konfliktløs tilstand, som den gjorde det i Schmitts levetid, så mener jeg, at det er den modsatte pointe, der er den interessante: at liberalismen, under visse historiske forudsætninger, realt forøger striden. Denne pointe er eks. hovedbudskabet $i$ en lang række af Schmitts 1920'er-analyser af Weimarrepublikken. Analyserne fokuserer på de magtgevinster og -skævvridninger, som det parlamentariske demokrati muliggør. De peger endvidere på, at det 'folk', der er demokratiets grundlag, i dets altid diffuse heterogenitet er formbart og manipulerbart for de, der har interesse i det og midler dertil.

I disse og beslægtede diagnostiske og kritiske analyser ligger også Schmitts potentielle betydning for demokratiovervejelser i dag. Ikke i hans forsøg på i Weimartiden at formulere en alternativ demokratimodel til parlamentarismen, hvilket - som Dyrberg, Hviid Pedersen og Harste udstiller det - mildt sagt er helt til rotterne.

Endvidere savner jeg en refleksion over forholdet mellem Schmitts forståelse af 'politik', 'ret' og 'politisk teologi'. Flere af bidragyderne efterlyser i Schmitts politikforståelse reguleringsidealer for en samfundsorden. Men forfatterskabets ideer og idealer om samfundsregulering ligger ikke i Schmitts politikforståelse, men $i$ hans forståelse af 'ret' og i hans 'politiske teologi'. Hvor det politiske' udgør det altid tilstedeværende stridsgrundlag, består rettens opgave i at hæmme eller relativere striden. Den 'politiske teologi' peger på betydningen af strukturelle relationer mellem en tids jura, politik og religion/ metafysik. Det ville have været spændende, om antologiens analyser af Schmitts politik-forståelse havde været suppleret med analyser af hans forståelse af forholdet mellem politik, ret og religion.

Disse forbehold skal dog på ingen måde afholde mig fra at anbefale antologien på det varmeste. Den er yderst velkommen; dels for de præcise analytiske afklaringer, der advarer imod en ureflekteret overtagelse af de Schmittske begreber; men især for de konkrete påmindelser om samtidige fænomener, der - synligt og usynligt, gennem umærkelige forskydninger såvel som gennem tydelig voldseskalering - truer med at underminere demokrati og retsstat indefra.

Christiane Mossin

\section{Da fribeden (ncesten) dode som problem}

Quentin Skinner: Hobbes and Republican Liberty. Cambridge University Press 2008, 245 sider., $\$ 22.99$

Der er ikke de store overraskelser gemt i titlen på Quentin Skinners seneste udgivelse om intellektuel historie. Tværtimod kunne man sige, for på trods af at Skinner - i det mindste i en dansk kontekst - ofte læses på grund af metodologiske pointer, så 